\title{
Combined effects of irrigation management and nitrogen fertilization on soft wheat productive responses under Mediterranean conditions
}

\author{
Patrícia Oliveira ${ }^{1}$, Manuel Patanita ${ }^{1,2}$, José Dôres ${ }^{1}$, Luis Boteta ${ }^{3}$, José Ferro Palma ${ }^{1}$, Maria Isabel Patanita ${ }^{1}$, Isabel \\ Guerreiro $^{1}$, José Penacho ${ }^{1}$, Maria Natividade Costa $^{1}$, Elizabete Rosa ${ }^{1}$, and Alexandra Tomaz ${ }^{1,2, *}$ \\ ${ }^{1}$ Escola Superior Agrária - Instituto Politécnico de Beja. R. Pedro Soares S/N, 7800-295 Beja, Portugal. \\ ${ }^{2}$ GeoBioTec, Universidade Nova de Lisboa. Campus da Caparica, 2829-516 Caparica, Portugal \\ ${ }^{3}$ Centro Operativo e de Tecnologia de Regadio, Quinta da Saúde, Apartado 354, 7801-904 Beja, Portugal
}

\begin{abstract}
To evaluate water-nitrogen interactions on irrigated wheat production, it is important to know: the dose, the fractioning, and the most recommended period of fertilizers application; the best irrigation volumes and schedules for meeting the crop requirements, ensuring the minimum leaching risks, to obtain the highest yields and quality of the grain, while achieving high water and nitrogen use efficiencies. This study evaluated the interactive effect of irrigation and nitrogen fertilization, with conventional and enhanced efficiency fertilizers, on yield, irrigation water use efficiency and grain quality of soft wheat. For this purpose, two trials were carried out during the 2016/2017 in Beja, Alentejo, under two irrigation strategies: D1 (100\% of crop evapotranspiration - ETc - throughout the cycle) and D2 (100\% of ETc only at four stages: beginning of stem extension; booting; heading; grain filling). In one trial, enhanced efficiency $\mathrm{N}$ fertilizers were applied through 6 splitting treatments. In the other, conventional $\mathrm{N}$ fertilizer was applied through 5 splitting treatments. The results suggest that, on one hand, early applications of advanced efficiency fertilizers do not compromise the crop yield and, on the other hand, the availability of nitrogen in the booting stage is important to obtain higher grain protein content.
\end{abstract}

\section{Introduction}

According to [1], the contribution of Portugal for soft wheat (Triticum aestivum L.) production in de EU-28 represents only $0.05 \%$ in a production area of $0.13 \%$. Thus, Portugal is an importer of common wheat and this situation is difficult to overcome given some less optimal climate conditions and the market fluctuations for farmers to obtain high yields and incomes from this crop. Wheat yield responses to water and nitrogen vary widely among different environments and yield gaps can be shifted due to technological, environmental, or economic factors [2]. Nitrogen is a key element in obtaining high yields and its content is widely regarded as the main factor that can directly affect the storage of protein in the grain, as well as its technological quality. The availability of nitrogen during the booting stage may contribute to a higher protein content of the grain, a desirable quality in wheat for baking [3,4]. Wheat water use depends on cultivar, growth stage, climatic conditions, water availability, soil, and crop management practices [5]. In regions with a Mediterranean-type climate, the balance between the key climate variables and the most critical stages of wheat growth, especially the grain filling stage, implies that the success of the crop depends to a very large degree on the knowledge of proper water management combined with suitable fertilization strategies $[5,6]$.

Therefore, in order to meet the crop requirements and improve the use efficiency of water and nitrogen, it is necessary to find a compromise in management between quantitative and qualitative aspects, by adjusting the type of fertilizer, the dose, the fractioning, and the most recommended period of application, as well as appropriate irrigation volumes and schedules [7]. In this study, we evaluate the interactive effect of irrigation and nitrogen $(\mathrm{N})$ fertilization strategies, with conventional and enhanced efficiency $\mathrm{N}$ fertilizers, on yield and grain quality parameters of soft wheat (cv. Antequera) irrigated with center-pivot in the Mediterranean region of Baixo Alentejo (South Portugal).

\section{Materials and methods}

\subsection{Study and site description}

Two trials were carried out during 2016/2017 in Beja, Baixo Alentejo (Southern Portugal) with the cultivar 'Antequera', a cultivar of improver wheat, used for

\footnotetext{
* Corresponding author: atomaz@ipbeja.pt
} 
bread, pastry and flour. Wheat was sown on January 24 and the harvest took place on June 24, 2017. The experimental design was split-plot with two irrigation treatments as main plots and $\mathrm{N}$ fertilizer (165 kg N/ ha) splitting and timing of application treatments as subplots (Tables 1 and 2). More specifically, six treatments in trial 1, with Enhanced Efficiency fertilizers - stabilized (A1 to A5) and controlled-release (A6) - and five treatments in the trial 2 (A1 to A5), with conventional fertilizers, with three replications.

Table 1. Nitrogen fertilizer splitting and timing treatments through the wheat cycle in trial 1, with Enhanced Efficiency N fertilizers. Crop stages dates between brackets.

\begin{tabular}{|c|c|c|c|c|c|}
\hline \multirow{2}{*}{ Treatment } & \multicolumn{5}{|c|}{ \% N total } \\
\cline { 2 - 6 } & $\begin{array}{c}\text { Sowing } \\
\text { (24-Jan) }\end{array}$ & $\begin{array}{c}\text { Tillering } \\
\text { (01-Mar) }\end{array}$ & $\begin{array}{c}\text { Stem } \\
\text { extension } \\
\text { (25-Mar) }\end{array}$ & $\begin{array}{c}\text { In boot } \\
\text { (14-Apr) }\end{array}$ & $\begin{array}{c}\text { Heading } \\
\text { (24-Apr) }\end{array}$ \\
\hline A1 & 100 & & & & \\
\hline A2 & 50 & & & 50 & \\
\hline A3 & 50 & & 25 & & 25 \\
\hline A4 & 75 & & & 25 & \\
\hline A5 & 75 & & 25 & & \\
\hline A6 & 100 & & & & \\
\hline
\end{tabular}

A1 to A6 - Nitrogen fertilizer splitting/timing treatments; A1 to A5 Stabilized fertilizer; A6 - Controlled release fertilizer

Table2. Nitrogen fertilizer splitting and timing treatments through the wheat cycle in trial 2, with conventional $\mathrm{N}$ fertilizers. Crop stages dates between brackets.

\begin{tabular}{|c|c|c|c|c|c|}
\hline \multirow{2}{*}{ Treatment } & \multicolumn{5}{|c|}{ \% N total } \\
\cline { 2 - 6 } & $\begin{array}{c}\text { Sowing } \\
\text { (24-Jan) }\end{array}$ & $\begin{array}{c}\text { Tillering } \\
\text { (01-Mar) }\end{array}$ & $\begin{array}{c}\text { Stem } \\
\text { extension } \\
\text { (25-Mar) }\end{array}$ & $\begin{array}{c}\text { In boot } \\
\text { (14-Apr) }\end{array}$ & $\begin{array}{c}\text { Heading } \\
\text { (24-Apr) }\end{array}$ \\
\hline A1 & 33 & 33 & 33 & & \\
\hline A2 & 25 & 25 & 25 & & 25 \\
\hline A3 & 25 & 25 & 25 & 25 & \\
\hline A4 & & 50 & & 25 & 25 \\
\hline A5 & 50 & & 25 & 25 & \\
\hline
\end{tabular}

A1 to A5- Nitrogen fertilizer splitting/timing treatments

Irrigation treatments were: D1 - $100 \%$ of crop evapotranspiration (ETc) throughout the cycle, and D2 $100 \%$ of ETc only at four stages (beginning of stem extension; booting; heading; grain filling). The climate in the region is Mediterranean or Temperate with hot and dry summer (Csa, in Köppen classification). The 30year-long period mean value of annual rainfall and average temperature in the region are $558 \mathrm{~mm}$ and $16.9^{\circ} \mathrm{C}$, respectively [8]. Soils in the study area are predominantly Calcic Cambisols.

\subsection{Meteorological data}

Meteorological data were recorded in an automatic weather station, belonging to the SAGRA agro- meteorological network support service to farmers in the Alentejo region [9].

\subsection{Irrigation}

Irrigation was performed by a center-pivot system. The irrigation dose and schedule were evaluated using the MOGRA model [10], that performs a daily soil water balance, based on the FAO methodology for computing crop water requirements [11] using the meteorological data and soil water content information registered with capacitance probes. The total irrigation volumes applied during the growth cycle were $2527 \mathrm{~m}^{3} / \mathrm{ha}$ and 1723 $\mathrm{m}^{3} /$ ha, in irrigation treatments $\mathrm{D} 1$ and $\mathrm{D} 2$, respectively.

\subsection{Yield and quality evaluation}

Yield and yield components evaluated were grain yield $(\mathrm{kg} / \mathrm{ha})$, number of spikes $/ \mathrm{m}^{2}$ and 1000 -grain weight $(\mathrm{g})$. The grain quality evaluation included the parameters hectoliter weight $(\mathrm{HLW})(\mathrm{kg} / \mathrm{hl})$ and grain protein content (GPC) (\%).

\section{Results and discussion}

\subsection{Climate and water requirements}

Given the climatic conditions of 2017 , a very dry year, high water requirements were felt from the beginning of March, when the crop was entering the tillering stage (Fig. 1).

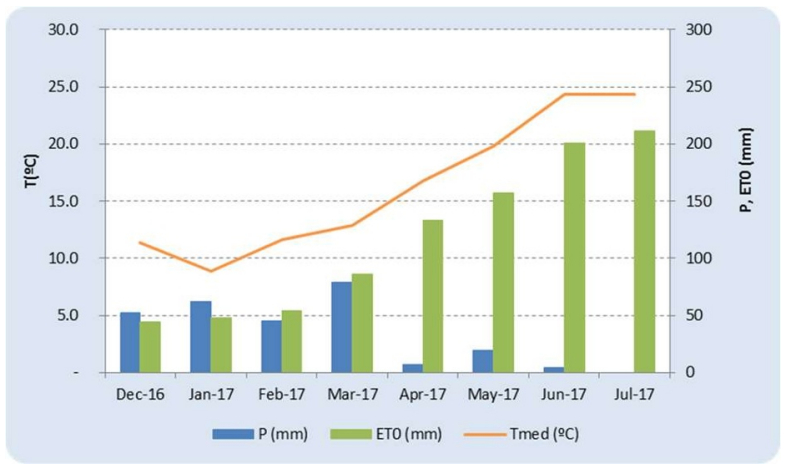

Figure 1. Monthly average daily temperature (Tmed), monthly precipitation $(\mathrm{P})$ and monthly reference evapotranspiration (ET0) during the growing season from December 2016 to July 2017.

As showed in Figure 2, the 1st irrigation in D1 treatment took place on March 11. In D2 irrigation began on March 17, between the end of the tillering and the start of stem extension.

Irrigations became more frequent after April, as temperature and evapotranspiration increased. Differences between the two irrigation strategies tested were the applied volumes and the irrigation schedules: in D1, every time the soil water balance showed an oncoming water deficit, irrigations aimed at the replenishment of the total available soil water, with 2 to 15 days intervals; in D2, following the criterion defined 
for this strategy, irrigations were carried out every $15-20$ days until May. After, given the high water requirements of the crop in the flowering and, mainly, grain filling stages, irrigations were applied weekly. Last irrigation took place on June 1st, in both D1 and D2.

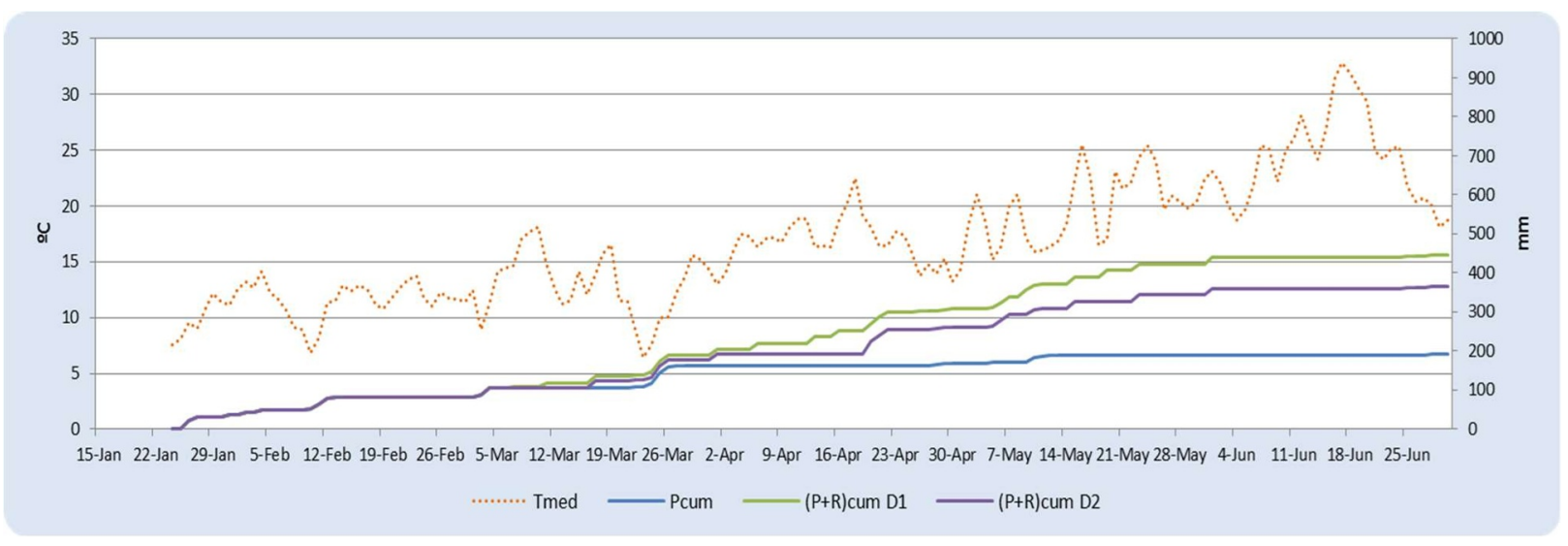

Figure 2. Daily average air temperature (Tmed), cumulative rainfall (Pcum) and cumulative precipitation plus irrigation in D1 treatment $((P+R)$ cum D1) and in D2 treatment $((P+R)$ cum D2) during the growing season from January to June 2017.

\subsection{Yield and grain quality}

In trial 1 only the number of spikes $/ \mathrm{m}^{2}$ showed significant influence of the irrigation regime, the highest value being registered in the D1 treatment (Table 3). Significant effects of split/time of $\mathrm{N}$ fertilizer application occurred.

Table3. Effect of the irrigation strategy and splitting/timing of nitrogen fertilization with Enhanced Efficiency $\mathrm{N}$ fertilizers on number of spikes $/ \mathrm{m}^{2}, 1000$-grains weight, yield, hectoliter weight (HLW) and grain protein content (GPC).

\begin{tabular}{|c|c|c|c|c|c|}
\hline $\begin{array}{l}\text { Source of } \\
\text { variation }\end{array}$ & $\begin{array}{l}\text { No } \\
\text { spikes/m }\end{array}$ & $\begin{array}{l}1000- \\
\text { grains } \\
\text { weight } \\
\text { (g) }\end{array}$ & $\begin{array}{l}\text { Yield } \\
\text { (kg/ha) }\end{array}$ & $\begin{array}{l}\text { HLW } \\
(\mathrm{kg} / \mathrm{hl})\end{array}$ & $\begin{array}{l}\text { GPC } \\
(\%)\end{array}$ \\
\hline $\begin{array}{l}\text { Irrigation } \\
\text { strategy } \\
\text { D1 } \\
\text { D2 } \\
\end{array}$ & $\begin{array}{l}* \\
396 \mathrm{a} \\
354 \mathrm{~b} \\
\end{array}$ & $\begin{array}{l}\text { n.s. } \\
42.52 \\
40.03 \\
\end{array}$ & $\begin{array}{l}\text { n.s. } \\
4594 \\
3942 \\
\end{array}$ & $\begin{array}{l}\text { n.s. } \\
80.63 \\
80.52 \\
\end{array}$ & $\begin{array}{l}\text { n.s. } \\
15.61 \\
16.32 \\
\end{array}$ \\
\hline $\begin{array}{l}\text { Fertilizer } \\
\text { splitting } \\
\text { /timing } \\
\text { A1 } \\
\text { A2 } \\
\text { A3 } \\
\text { A4 } \\
\text { A5 } \\
\text { A6 }\end{array}$ & $\begin{array}{l}\text { n.s. } \\
335 \\
397 \\
373 \\
373 \\
400 \\
371 \\
\end{array}$ & $\begin{array}{l}\text { n.s. } \\
41.04 \\
42.44 \\
40.67 \\
42.14 \\
41.66 \\
39.71 \\
\end{array}$ & $\begin{array}{l}* \\
4170 \mathrm{ab} \\
3929 \mathrm{~b} \\
4126 \mathrm{ab} \\
4458 \mathrm{ab} \\
4564 \mathrm{a} \\
4361 \mathrm{ab}\end{array}$ & $\begin{array}{l}\text { n.s. } \\
80.75 \\
79.68 \\
81.05 \\
80.03 \\
81.10 \\
80.82 \\
\end{array}$ & $\begin{array}{l}* \\
14.71 \mathrm{~d} \\
17.38 \mathrm{a} \\
16.36 \mathrm{~b} \\
16.47 \mathrm{~b} \\
15.51 \mathrm{c} \\
15.36 \mathrm{c}\end{array}$ \\
\hline Interaction & n.s. & n.s. & n.s. & n.s. & $*$ \\
\hline
\end{tabular}

Different letters indicate statistically significant differences $(\mathrm{p}<0.05)$ by the Tukey test; * - significance for $\mathrm{p}<0.05$; n.s. - no significance for $\mathrm{p}<0.05$. D1 and D2 - Irrigation treatments; A1 to A6 - Nitrogen fertilizer splitting/timing treatments; A1 to A5 - Stabilized fertilizer; A6 - Controlled release fertilizer.

Yield was higher in the A5 treatment, showing that early $\mathrm{N}$ applications with this type of fertilizers do not compromise $\mathrm{N}$ availability throughout the wheat grow cycle and therefore the grain production. GPC was higher in the A2 treatment, indicating the importance of $\mathrm{N}$ availability at the booting stage in order to obtain grains with desirable quality traits.
In trial 2 significantly higher yields and 1000-grains weights were obtained in the D1 irrigation treatment (Table 4).

Table4. Effect of the irrigation strategy and splitting/timing of nitrogen fertilization with conventional $\mathrm{N}$ fertilizers on number of spikes $/ \mathrm{m}^{2}$, 1000-grains weight, yield, hectoliter weight (HLW) and grain protein content (GPC).

\begin{tabular}{|l|l|l|l|l|l|}
\hline $\begin{array}{l}\text { Source of } \\
\text { variation }\end{array}$ & $\begin{array}{l}\text { No } \\
\text { spikes } \\
/ \mathbf{m}^{2}\end{array}$ & $\begin{array}{l}\mathbf{1 0 0 0 -} \\
\text { grains } \\
\text { weight } \\
\mathbf{( g )}\end{array}$ & $\begin{array}{l}\text { Yield } \\
\mathbf{( k g / h a )}\end{array}$ & $\begin{array}{l}\text { HLW } \\
\mathbf{( k g} / \mathbf{h l})\end{array}$ & $\begin{array}{l}\text { GPC } \\
\mathbf{( \% )}\end{array}$ \\
\hline $\begin{array}{l}\text { Irrigation } \\
\text { strategy }\end{array}$ & n.s. & $*$ & $*$ & $n . s$. & n.s. \\
D1 & 393 & $41.56 \mathrm{a}$ & $5614 \mathrm{a}$ & 80.42 & 16.44 \\
D2 & 371 & $39.00 \mathrm{~b}$ & $3488 \mathrm{~b}$ & 80.70 & 16.89 \\
\hline Fertilizer & & & & & \\
splitting & & & & & \\
/timing & n.s. & n.s. & n.s. & n.s. & n.s. \\
A1 & 400 & 40.05 & 4694 & 80.55 & 15.94 \\
A2 & 390 & 40.79 & 4688 & 80.90 & 16.94 \\
A3 & 386 & 40.99 & 4686 & 80.70 & 17.14 \\
A4 & 381 & 38.71 & 4535 & 80.47 & 16.71 \\
A5 & 354 & 40.86 & 4154 & 80.18 & 16.57 \\
\hline Interaction & n.s. & n.s. & n.s. & n.s. & n.s. \\
\hline
\end{tabular}

Different letters indicate statistically significant differences $(\mathrm{p}<0.05)$ by the Tukey test; * - significance for $\mathrm{p}<0.05 ;$ n.s. - no significance for $\mathrm{p}<0.05$. D1 and D2 - Irrigation treatments; A1 to A5 - Nitrogen fertilizer splitting/timing treatments.

\section{Conclusions}

In trial 1, with no significant differences in wheat yield between irrigation treatments, the results may point to a greater efficiency in irrigation water use in the deficit irrigation strategy, D2, suggesting that water applied at the beginning of stem extension, anthesis and grain filling stages is used more efficiently by the crop.

The results indicate that early applications of gradual release fertilizers do not compromise the availability of $\mathrm{N}$ throughout the crop cycle and, consequently, the grain yield. 
It was also observed that the availability of $\mathrm{N}$ in the booting stage is important to obtain higher levels of grain protein.

\section{Acknowledgement}

Publication supported by the Polish Ministry of Science and Higher Education as a part of the program of activities disseminating science from the project „Organization of the First International Science Conference - Ecological and Environmental Engineering”, 26-29 June 2018, Kraków.

This study was supported by the Project INTERATrigo (Yield and quality evaluation in wheat as a function of water-nitrogen interactions), POCI-01-0145-FEDER023262 e LISBOA-01-0145-FEDER-023262 (SAICTPOL/23262/2016), funded by FEDER through the COMPETE2020 and PORLisboa Programs and the FCT / MCTES through national funds (PIDDAC). This work is also a contribution to the Project UID/GEO/04035/2013, funded by FCT - Fundação para a Ciência e a Tecnologia, Portugal.

\section{References}

1. EUROSTAT. Wheat and spelt by area, production and humidity (EUROSTAT Products datasets, 2018) http://ec.europa.eu/eurostat/web/productsdatasets/-/tag00047
2. K.G. Cassman, A. Dobermann, D.T. Walters, H. Yang. Annu. Rev. Environ. Resour. 28, 315-358 (2003)

3. M. Blandino, F. Marinaccio, P. Vaccino, A. Reyneri.. Agron. J., 107 (4), 1584-1594 (2015)

4. M.N. Costa, M. Patanita. Grandes Culturas 3, 2629 (2016)

5. L. Boteta. Gestão da Rega do Trigo. Grandes culturas 1,18-21 (2013)

6. A. Alghory, A. Yazar. Agric. Water Manag. 203, 395-404 (2018)

7. A. Tomaz, M. Patanita, I. Guerreiro, J. Dôres, L. Boteta, J. Ferro Palma. Span. J. Soil Sci., 8 (1), 1223 (2018)

8. IPMA. Normais climatológicas 1981-2010 provisórias de Beja (Instituto Português do Mar e da Atmosfera, 2016) https://www.ipma.pt/pt/oclima/normais.clima/198 1-2010/002/

9. COTR. SAGRA - Sistema Agrometeorológico para a Gestão da Rega no Alentejo (Centro Operativo e de Tecnologia de Regadio, 2017) http://www.cotr.pt/cotr/sagra II/

10. COTR. MOGRA - Modelo de Gestão da Rega para o Alentejo (Centro Operativo e de Tecnologia de Regadio, 2017) http://www.cotr.pt/cotr/sagra.asp

11. R.G. Allen, L.S. Pereira, M. Raes, M. Smith. Crop evapotranspiration guidelines for computing water requirements. (FAO Irrig. and Drain. Paper 56, FAO. Rome, Italy, 1998) 